鹿児島県医師会災害医療チームによる 2016 年熊本地震における 避難所感染対策支援活動

\author{
川村 英樹 ${ }^{1.2} \cdot$ ・德田 浩一 ${ }^{1,2)} \cdot$ 川上 雅之 ${ }^{2)} \cdot$ 有村 敏明 ${ }^{2)}$ \\ 川口（辰哉 ${ }^{3)} \cdot$ 松井 $\quad$ 珠乃 ${ }^{4)} \cdot$ 西 順一郎 ${ }^{1,2}$
}

\title{
Support for Infection Control in Evacuation Centers Following 2016 Kumamoto Earthquakes by Kagoshima Prefecture Medical Association Team
}

\author{
Hideki KAWAMURA ${ }^{1,2)}$, Koichi TOKUdA ${ }^{1,2)}$, Masayuki KAWAKAMI ${ }^{2)}$, Toshiaki ARIMURA ${ }^{2)}$, \\ Tatsuya KAWAGUCHI ${ }^{3)}$, Tamano MATSUI ${ }^{4)}$ and Junichiro Nishi ${ }^{1,2)}$
}

\footnotetext{
${ }^{1)}$ Department of Infection Control and Prevention, Division of Medical and Environmental Safety, Kagoshima University Hospital,

2) Kagoshima Infection Control Team Network,

${ }^{3)}$ Department of Hematology and Infectious Diseases, Kumamoto University Graduate School of Medical Sciences,

4) Infectious Disease Surveillance Center, National Institute of Infectious Diseases
}

(2017 年 4 月 17 日受付・ 2017 年 7 月 6 日受理)

\begin{abstract}
要 旨
鹿児島県 JMAT（日本医師会災害医療チーム）では宇土市で感染対策チームを構成し，4月 21 日 (本震 5 日後) 〜 月 1 日に被災地医師会と自治体保健活動との協働で避難所感染対策支援活動 を行った，今回の研究の目的は避難所感染対策を検証し，有効性を検証することである. 各避難所 で把握された発熱者, 呼吸器・消化器の有症者数を調查票に記録し症候群サーベイランスを実施し た. 期間中 14 の指定避難所で 40 名の呼吸器・ 8 名の消化器の有症状者がみられたが, インフルエ ンザ・ノロウイルス感染症は除外された。設備・感染対策物品・衛生環境・隔離スペース等を巡回 時に確認し, リスクアセスメントを行ったが, 次亜塩素酸ナトリウムが不足し, トイレ清掃や吐物 処理物品の準備が不十分であった。次亜塩素酸ナトリウム等の必要物品配布やトイレ清掃・吐物処 理方法の指導, 感染症発症例への対応も併せて実施した。アウトブレイクの発生はなく, リスクア セスメントと症候群サーベイランスを活用した避難所感染対策支援活動は感染拡大防止に有用と思 われた。一方, 情報収集や活動内容に他の医療支援チームや保健師活動と重複するものもあり, 情 報共有が可能なスキームの確立が望まれる.
\end{abstract}

Key words：2016 年熊本地震, 災害支援, インフルエンザ, 感染性胃腸炎

序文

地震災害では水道を始めとしたライフラインの破たん や物資の不足が発生し衛生環境が悪化すること, また避 難所では狭い居住空間での生活を強いられることから, インフルエンザをはじめとした急性呼吸器感染症, 感染 性胃腸炎, 破傷風, 皮膚軟部組織感染症, 麻疹等さまざ

1) 鹿児島大学病院医療環境安全部感染制御部門，2)鹿児島感染制御 ネットワーク，3)熊本大学医学部附属病院感染免疫診療部, 4) 国立 感染症研究所感染症疫学センター第一室
まな感染症が拡大するリスクがある11.

JMAT（日本医師会災害医療チーム）は都道府県医師 会ごとにチームを編成し, 被災地の医師会からの要請に 基づいて派遣される. 鹿児島県 JMATは 4 月 17 日（本 震翌日）から宇土地区に派遣され，医療支援を中心とし た活動を開始した。宇土市は熊本市に隣接し熊本県中央 部に位置する東西に約 $20 \mathrm{~km}$, 南北に約 $7.5 \mathrm{~km}$, 総面 積約 $74 \mathrm{~km}^{2}$ の面積を有する（図 1), 人口約 3 万 7 千人 の自治体である。宇土市では 4 月 14 日の前震では震度 5 強, 4 月 16 日の本震では震度 6 強の震度が観測されて 


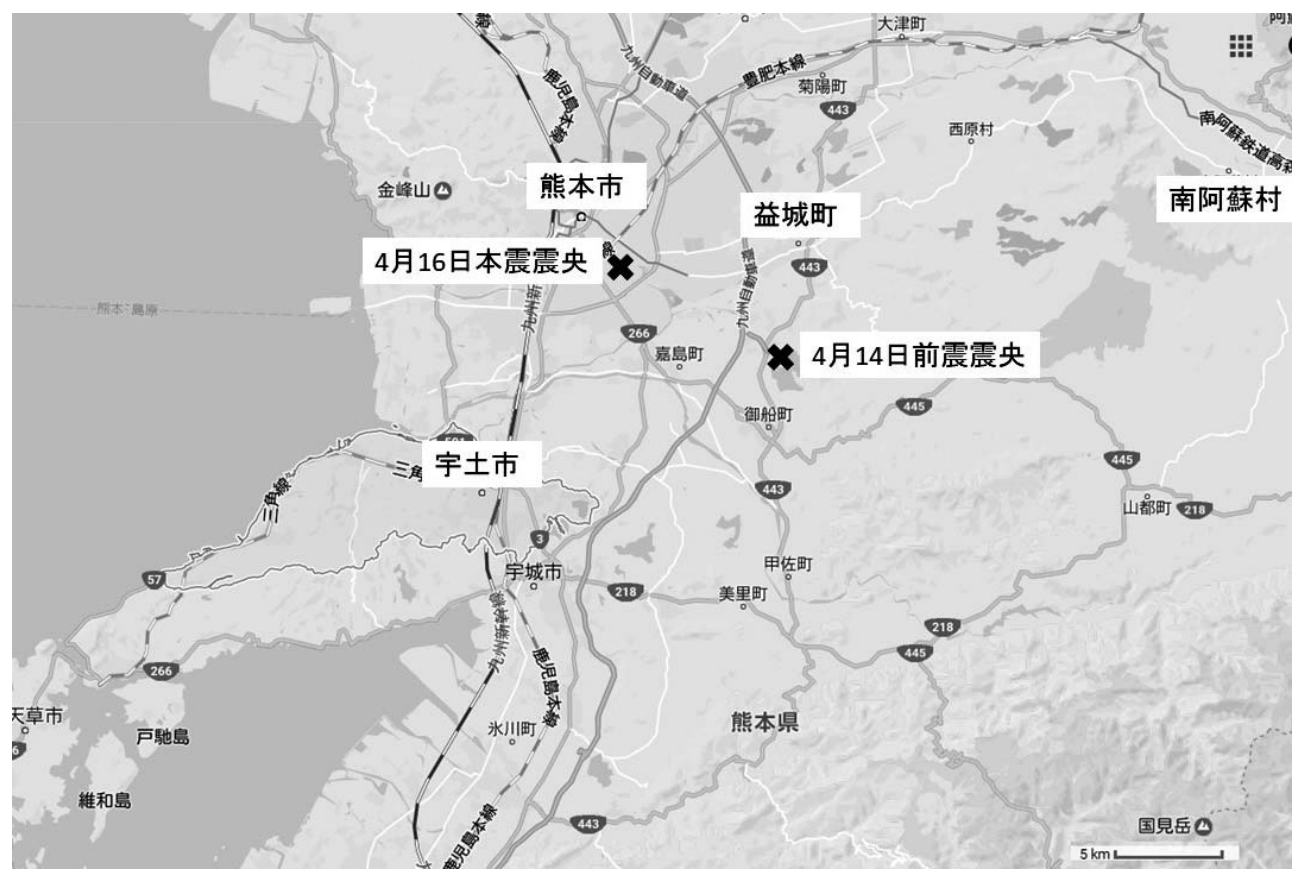

図 1 宇土市の位置 (Google マップを用い著者作成)

いる. 宇土市役所は 4 月 16 日の本震発生のために半壊 の被害が生じた。このため発桨直後は支援物資や支援団 体の受け入れにも混乱が生じていた。 その後市役所機能 は市民体育館に移され, 行政は災害前に作成された地域 防災計画に基づき活動を開始した。この市民体育館の中 に医療救護班本部と救護所が設置され，ここで鹿児島県 JMAT は宇土地区医師会・宇土市健康福祉部, 愛知県 ・ 佐賀県から派遣された保健活動応援チーム，リハビリ・ 歯科・精神医療チームとミーティングを行い，医療支援 活動を展開した。

宇土市の家屋・建物の倒壊は多くはないが, 水道は被 災直後各地で断水した. ピーク時（4/16）は 14 か所の 避難所に 3000 人が避難し, その後も, 夜間の地震に対 する恐怖から，夜のみ避難する住民が多い状況であった． 我々が活動を行った本震 1 週間後でも日中の避難者は約 500 人であったが, 夜間は約 1500 人が避難し, うち車 中泊をする避難者は約 600 人存在した.

JMAT の活動には, 被災者医療とともに感染症対策 を含む公衆衛生活動も含まれており, 避難所での感染対 策に特化した支援活動が必要という判断の下，4月 18 日現地・熊本県医師会から鹿児島県医師会へ感染対策 チームの派遣依頼があった。それに応じて，鹿児島県下 の医療機関で感染対策活動を行っている鹿児島感染制御 ネットワークの会員の感染制御医師 (ICD) が各班 1-2 名, 感染管理認定看護師が各班 1 名でチームを組み, 4 月 21 日（本震後 5 日）～5 月 1 日（同 15 日）にかけて, 5 班に分かれて活動した。

本研究の目的は, 鹿児島感染制御ネットワークによる
感染対策に特化した JMAT（以下感染対策 JMAT）活 動による避難所での感染対策を検証し，その有効性を検 証することである.

\section{方法}

感染対策 JMAT は 14 の指定避難所（図 2）をすべて 巡回し, 発熱・呼吸器症状・消化器症状を避難所毎に毎 日把握する症候群サーベイランスの構築，避難所毎の感 染管理に関するリスクアセスメントの実施と必要物品の 配布, 感染症が発生した場合の対応を主な活動として 行った.

症候群サーベイランスは, 観察調査, 聞き取りおよび 自己申告によって把握された発熱・呼吸器症状・消化器 症状の有症状者の人数について, 避難所管理を行う日々 の担当者が調査票に記載し, 朝の勤務交代後に医療救護 班本部に提出してもらい, この報告を基に感染対策 JMAT が状況を確認することとした.

リスクアセスメントは避難所を巡回し, 兵庫県立大学 ${ }^{2)}$ および東北感染症危機管理ネットワーク ${ }^{3)}$ が作成したリ スクアセスメントシートを参考に新たに作成し（表 1)， 感染対策 JMAT がシートを基に避難所の基本情報・設 備の復旧に加え, 清掃・ごみ処理, 感染対策物品の充足 状況，トイレの状況・衛生状況，手洗い実施状況，室内 環境, 隔離用部屋の有無などを避難所管理者からの聞き 取りと実際の状況について確認することで評価し, 問題 点を抽出した.リスクアセスメントの項目の中でも感染 物品の管理方法やトイレの状況, 手洗いの状況について は特に管理者と一緒に確認することで, リスク共有を 


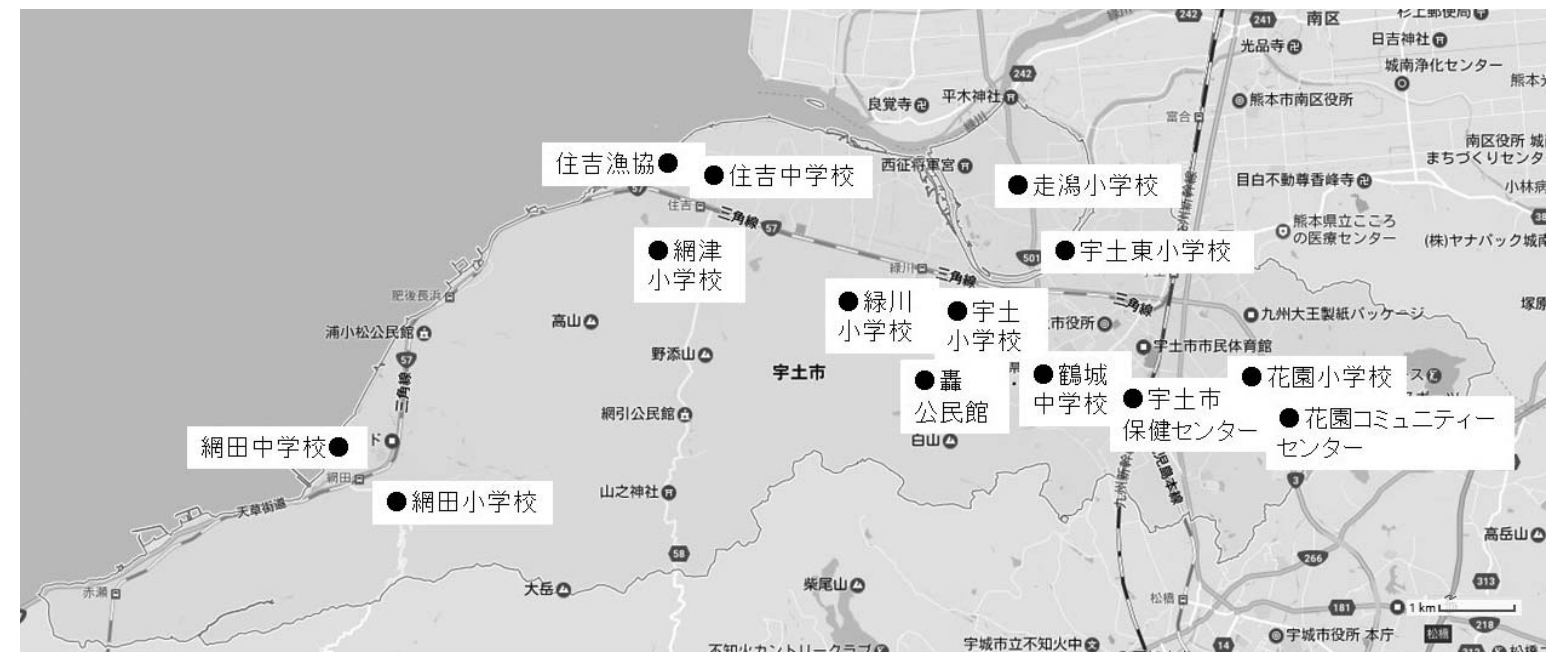

図 2 宇土市に設置された 14 の指定避難所（Google マップを用い著者作成）

図った。

宇土地区医師会との話し合いで，避難所でインフルエ ンザや感染性胃腸炎患者が発生した場合, 必要に応じて 発症者の隔離目的入院と, インフルエンザ濃厚接触者へ の抗インフルエンザ薬予防投与を検討する方針となった.

\section{結果}

\section{1）症候群サーベイランス}

感染対策 JMAT 活動期間中 14 の指定避難所で 40 名 の呼吸器・ 8 名の消化器の有症状者がみられた。消化器 症状はすべて散発例であり, ノロウイルス感染症は医療 機関受診によって除外された。最も症状の多かった呼吸 器症状は, 1 避難所で 4 月 21 日から 25 日に 27 名の有 症状者集積像が見られたが，インフルエンザは医療救護 班や医療機関受診によって除外され，その後終息した。

\section{2)リスクアセスメント}

感染対策 JMAT が活動を開始した時点で水道は復旧 しており，アルコール手指消毒薬やサージカルマスクは 充足していたが，移動歩行能力の低下した高齢者も多く， 手洗い場での流水と石瞼による手洗いが困難な場面もあ り，アルコールクロスによる清拭消毒を代用している場 面もみられた。断水に備え, また設置された簡易トイレ 周辺に手洗い場がないため, 給水タンクやバケツに貯め 水を行っている避難所もみられ, 水管理が困難であった. また手洗い用の流し場が，手洗いだけでなく清掃用具の 清掃や野菜の水洗いなどと共用して使われている箇所が あり，手洗い場のゾーニングを図った（図 3)。避難所 では地元の住民が食材を持参し炊き出しを行っており, ここでは手指衛生の指導も行った。避難所の多くは学校 であったが, 授業の再開に向けた準備が行われており, 教室や保健室等の利用が困難であり, 感染症発症者が出 現した場合でも，隔離スペースを確保できるところはほ
とんどなかった.

宇土市の避難所は比較的居住スペースは確保されてい たものの, 土足で避難所の入り口では履き替えが行われ ていない, 就寝に体操用マットを使用している, 避難ス ペースに廊下が使用され，またペットが屋内の避難ス ペースにいる避難所もみられた。

ごみの分別は比較的行われていたが，ごみ集積場が避 難者の居住スペースに近接している箇所もみられた。

南阿蘇で感染性胃腸炎が疑われる避難者が多数出現し たとの報道が 4 月 23 日（本震後 7 日）あり, 各避難所 でも感染性胃腸炎に対する注意喚起がなされた。しかし， 次亜塩素酸ナトリウムが各避難所に届いておらず，塩化 ベンザルコニウムやアルコールなどでトイレ清掃が行わ れている避難所がみられた。 また配布された次亜塩素酸 ナトリウムには, 極めて低濃度で吐物処理やトイレ清掃 には使えないものもあり, 消毒薬の適正使用が必要で あった。

\section{3）感染症発症例への対応}

活動開始にあたり，宇土地区医師会と申し合わせを行 い，避難所でインフルエンザが発生し，自宅への帰宅が 困難な場合は医療機関への入院を考慮すること, また避 難所にいる家族等約 $2 \mathrm{~m}$ 以内の範囲で発症者とともに 避難していた濃厚接触者に対しては宇土地区医師会が購 入した抗インフルエンザ薬（オセルタミビル $75 \mathrm{mg} 1$ 日 1 回 3 日間）の予防投与を考慮することとした。 ま た，ノロウイルス迅速検査陽性または検査陰性でも感染 性胃腸炎が疑われる場合は自宅に帰宅が可能な場合は可 能な限り帰宅していただき，避難所内，またはスペース 確保が困難な場合は医療機関等を活用して隔離を実施し, 隔離期間は下痢改善後 2 日（衛生行動ができない場合等 は5日）とすることとした。

感染対策 JMAT 活動期間中, 3 例の B 型インフルエ 
表 1 避難所の感染管理リスクアセスメントシート

基本情報（責任者は、町内会長、保健所長など）

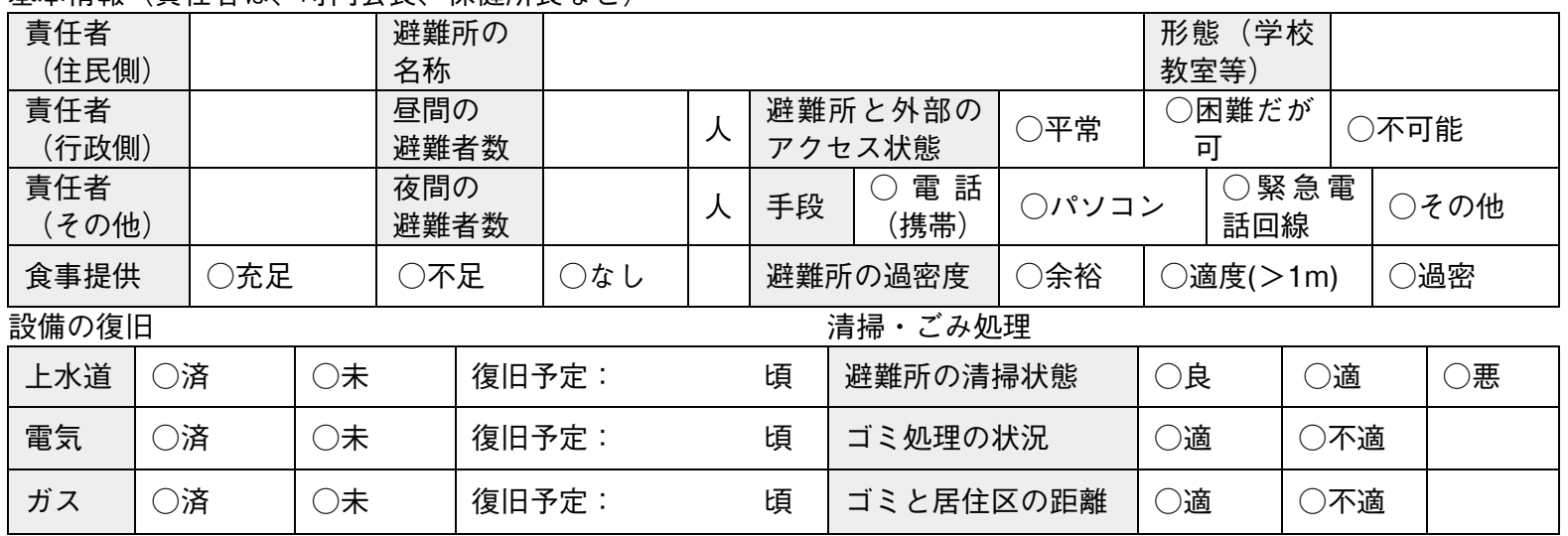

健康管理担当者（避難者の健康状態を広く把握できている人）

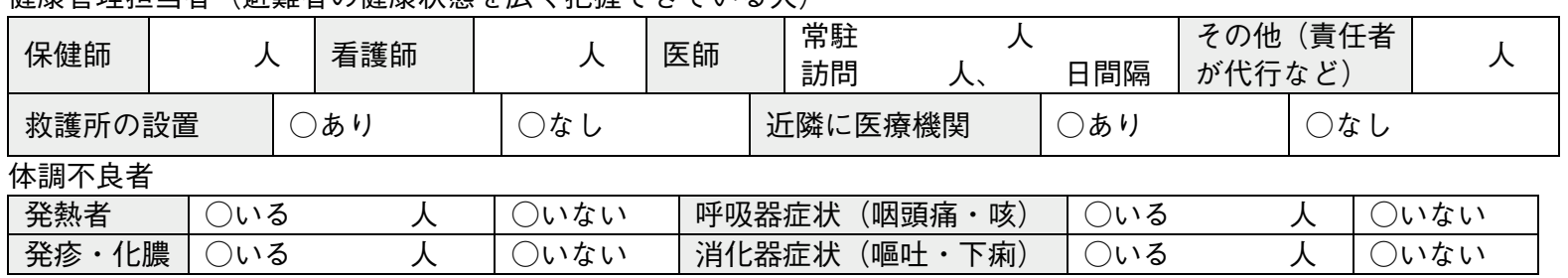

物品

\begin{tabular}{|l|l|l|l|l|l|l|l|}
\hline 石けん & $\bigcirc$ 充足 & $\bigcirc$ 不足 & $\bigcirc$ な & アルコール手指消毒剂 & ○充足 & ○不足 & ○し \\
\hline & & & & & & & \\
\hline マスク & ○充足 & ○不足 & ○なし & 次亜塩素酸 (ハイタ一など) & ○充足 & ○不足 & ○なし \\
\hline
\end{tabular}

トイレ・手洗いの励行

風呂・身体の清潔

\begin{tabular}{|l|l|l|l|l|l|l|}
\hline \multicolumn{2}{|l|}{ 使用可能トイレ } & \multicolumn{2}{l|}{ 個 } & \multicolumn{2}{l|}{ 簡枩数式 } \\
\hline トイレの数 & ○充足 & ○不足 & & トイレ水洗 & ○可 & ○不可 \\
\hline トイレの清掃 & ○実施 & ○未実施 & & 近所に浴場 & $\bigcirc$ ○ & ○なし \\
\hline トイレの衛生 & ○衛生的 & ○普通 & ○不衛生 & 着替え・下着交換 & ○実施 & ○不完全 \\
\hline & 流水手洗い & 消毒液手洗い & & おむつ・生理用品 & ○充足 & ○不足 \\
\hline トイレ後 & 可 $/$ 不可 & 可 $/$ 不可 & & 衛生的食器 & ○充足 & ○不足 \\
\hline 食前 & 可 $/$ 不可 & 可 $/$ 不可 & 食器・器具洗浄 & ○十分できる & ○不十分 & ○不可 \\
\hline 調理者 & 可 $/$ 不可 & 可 $/$ 不可 & & & & \\
\hline
\end{tabular}

室内環境の保全

感染・疾病予防対策

\begin{tabular}{|c|c|c|c|c|c|c|}
\hline 室内温度 & $\bigcirc$ 適 & ○不適 & & 換気 & ○実施 & ○未実施 \\
\hline 温度調整 & $\bigcirc$ 実施 & ○未実施 & & 屋内禁煙 & ○実施 & ○未実施 \\
\hline 毛布・布団 & ○充足 & ○不足 & ○なし & 掃除 & ○実施 & ○未実施 \\
\hline 寝具の下敷 & 充足 & ○不足 & ○なし & 居住区内外の履き替え & ○実施 & ○未実施 \\
\hline プライバシー保護（工夫） & $\bigcirc$ 実施 & ○未実施 & & 寝具乾燥 & ○実施 & ○未実施 \\
\hline 授乳場所 & ○あり & ○なし & & 感染症者の隔離用部屋 & ○あり & ○なし \\
\hline 着替え場所 & ○あり & ○なし & & おむつ・污物廃棄場所 & ○設置 & ○未設置 \\
\hline
\end{tabular}

ンザ発症例が報告された（表 2). 感染対策 JMAT のメ ンバーが訪問し, 他の有症状者の有無に加え発症者と他 の避難者の接触状況を評価した。 また, サージカルマス
クやアルコール手指消毒薬の充足状況を確認した. さら に, 避難所の過密状況を評価し, 保健所とも情報共有の 上で新たに有症状者が発生した場合の対応についても検 

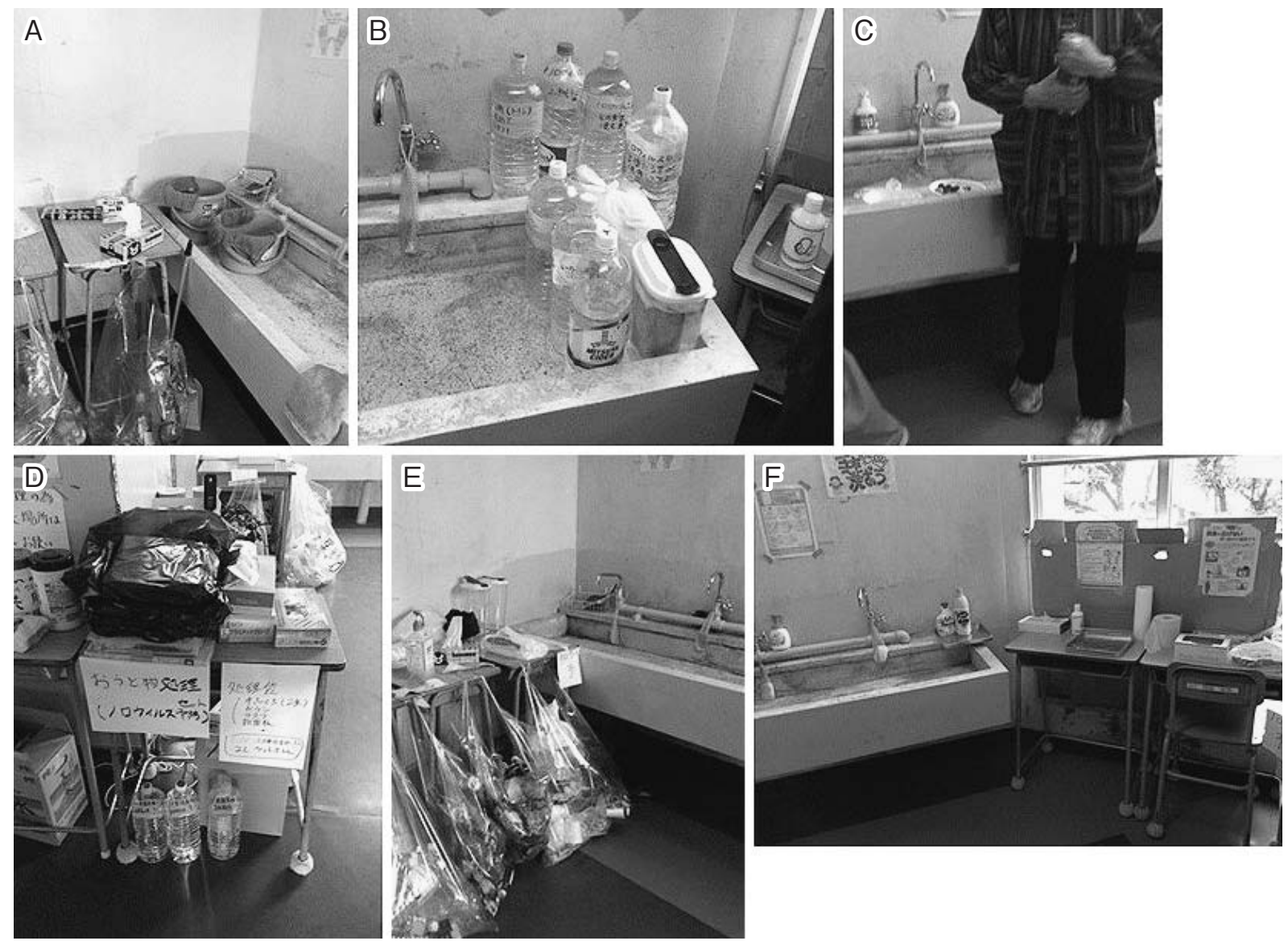

図 3 避難所の手洗い場の一例

清掃用具の保管場所（A）や次亜塩素酸ナトリウム希釈液の入ったペットボトルと飲料用の水，私用のコンタクトレンズ洗浄液の 保管場所 (B), 野菜の水洗いスペース (C) が同じ流し場で混在していた。避難所のボランティアの方々と話し合いを行い, 次車 塩素酸ナトリウム希釈液は吐物処理セットと一緒に別ゾーンに移動し (D), 清掃用具の保管場所も変更し (E), 手洗いスペースの 整理を行った（F）

表 2 インフルエンザ探知事例のまとめ

\begin{tabular}{|c|c|c|c|c|}
\hline 事例 & 探知日 & 探知の経路 & 発生場所 & 事例への対応 \\
\hline 1 & $2016 / 4 / 22$ & 医師会医師の巡回 & 指定避難所 & $\begin{array}{l}\text { 発症者とその家族は帰宅した. } \\
\text { 家族 }(6 \text { 人)・職員 }(5 \text { 人) ·同室者 }(10 \text { 人)にオセルタミビル予防投与を行った. }\end{array}$ \\
\hline 2 & $2016 / 4 / 25$ & 医療機関から & 非指定避難所 & $\begin{array}{l}4 \text { 名の発症者がおり, 探知時点で } 3 \text { 名は帰宅, } 1 \text { 名は別棟に移動していた. } \\
\text { 感染対策の確認を行い, 事例について保健所とも情報共有を行った. }\end{array}$ \\
\hline 3 & $2016 / 4 / 25$ & 医療機関から & 非指定避難所 & $\begin{array}{l}\text { 発症者は } 1 \text { 名で, 探知時点で帰宅していた. } \\
\text { 感染対策の確認を行い, 事例について保健所とも情報共有を行った. }\end{array}$ \\
\hline
\end{tabular}

討を行った．事例 1 では避難所が過密状態にあり，濃厚 接触した職員も確認されたことから, 同室者および濃厚 接触した職員に対し，オセルタミビルの予防投与を行っ た. 事例 2 では避難者に医療従事者がいたことから，隔 離や迅速な医療機関受診などの対応が行われていた。ま た避難所近くに寺社があり，隔離スペースが確保されて いたことが拡大の防止につながった，事例 3 でも迅速な 医療機関受診が行われていた。いずれの事例も対応後は
終息に至った。しかしながら, 事例 $2 \cdot 3$ は非指定避難 所のため, 行政からの情報では避難所の存在が確認でき なかった．このためサージカルマスクや手指消毒薬など を含む支援物資が届いていない状況もみられた。

\section{考察}

宇土市は市役所の損壊がありながら, 発災前の地域防 災計画で役割が明確にされていたことに加え, 職員の奮 
闘もあり，行政機能が比較的維持されていた。 また，宇 土地区医師会と宇土市は発災前から在宅医療等の活動で 良好な協力関係を構築し, Web 用いた連絡機能など も有していたこともあり, 発災直後から行政・地元医師 会を核に支援団体・自治体が一体化した活動が可能な状 態であり，東日本大震災でのサーベイランスや避難所感 染対策活動が発災後 20 日 ${ }^{4)}$ から 1 か月5) で開始されてい るのに対し, 今回の感染対策 JMAT は発災後 5 日とい う早期から活動を開始することが可能となった。災害時 の対応には災害医療では, 災害対応を行う医療組織の指 揮と統制 (Command and Control), 安全性 (Safety), 情報伝達（Communication）, 評価（Assessment）が重 要である ${ }^{6}$. 平時から災害時にも地元および支援団体が スムーズに活動できる体制を整備し，またチームワーク を構築できる関係づくりを形成しておくことが, 発災時 に円滑な活動を行うために重要と思われる。

有症状者のサーベイランスについては, 避難所から届 く情報によるものと, 医療救護班から届くものがある. 今回の感染対策 JMAT 活動では避難所管理者の情報に 基づいた紙ベースでの症候群サーベイランスシステムを 構築した. この形式では避難者の症状を観察して人数を 記録する手法により，各避難所の担当者に医学的知識が そしくても調査が可能であること, 医療機関受診者を対 象とするサーベイランスと比較すると, 避難所での状況 を把握することで受診行動の影響を受けず，またサーベ イランスの対象人数が多いことより早期探知に繋がると 考えられる. またサーベイランスを導入することにより， 症状出現に対する注意喚起にもつながる.一方, 感染症・ 非感染症の鑑別については医療救護班との連携も重要で ある. 熊本地震では, 医療救護チームが診療した患者情 報を毎日集計するシステム「J-SPPED（災害時診療概況 報告システム)」が, 初めて試験的に導入された. これ は医療救護チームが診療した被災者の年歯や性別のほか, 発熱や呼吸器 - 消化器症状の有無や麻疹症状 - 破傷風症 状などをチェックし，その日のうちに対策本部でデー夕 入力が行われる仕組みであり, 患者数が可視化されるこ とで迅速に対応できることが期待されている7)。それぞ れの特徵を検討し, 有用かつ負担の少ない感染症サーベ イランス体制や情報収集体制の構築が望まれる。今回の 震災の特徴として, 夜間の避難者とくに車中泊が多かっ たことが挙げられる. 車中泊の避難者は感染症症状の把 握が困難であり, 今回の活動でもこれら避難者の状況把 握ができず，避難者の自己申告がしやすくなるよう，注 意喚起を行うことや避難所管理者によるサーベイランス などの工夫も必要と思われる。また行政で把握できない 非指定避難所は巡回の対象に含まれておらず，医療機関 からの情報提供がなければ感染拡大につながった可能性 がある，非指定避難所に対する対応も重要であり，医療
機関等からの情報収集体制を構築しておく必要がある.

被災地で活動を行うには情報収集による活動のニーズ 把握が必要である。また被災状況・避難者数によって必 要な感染対策についても異なるため, リスクアセスメン トが活動の中心になる．避難者数の多い夜間はわれわれ の活動も十分とはいえず, とくにトイレの衛生状況や避 難所の過密状況, 食品の管理状況の評価については避難 所管理者の協力が重要と考える. またリスクアセスメン トの結果次亜塩素酸ナトリウムの不足とトイレ清掃で使 用する消毒薬選択が不適切であることが判明した。この ため, 次亜塩素酸ナトリウムを被災地に入る際に持参し, 応援自治体保健師活動チームと共に各避難所に吐物処理 セットやトイレ清掃用ポスター ${ }^{8)}$, 次亜塩素酸ナトリウ ムの希釈法が記載されたポスターととともに配布した. 現地では避難者自身のボランティア活動も行われており， 特にトイレ清掃には次亜塩素酸ナトリウムを使用するこ とと同時に, その希釈方法や環境清拭の手順, 便器の清 掃方法といったトイレ清掃方法も指導した. 今回の 2016 年熊本地震では南阿蘇で感染性胃腸炎が疑われる避難者 が多数発生したことで, 感染性胃腸炎に対する対策が重 要視されたが, 避難所での消毒薬適正使用が支援物資の 不足や管理体制の問題から難しい状況も見られた．被災 地に必要な物品が不足していることが判明した場合には 支援物品として送付できるような支援体制とともに，管 理者が適切な消毒薬を使用できるよう, マニュアルの作 成，感染対策の支援も重要と思われる.

一方，さまざまな支援団体が個別に情報収集を行うこ とは，避難所の職員・避難者に負担を伴う。したがって， 支援団体も組織化し, 情報共有を図ることは被災地側・ 支援側双方に有益なことと考えられる。JMATは医師 を中心としたチームの専門性と自己規律（プロフェッ ショナルオートノミー）に基づく行動として, 被災地医 師会を通じ，主に災害急性期以降における避難所等にお ける医療・健康管理活動を担うことを目的とし, その活 動内容には，感染症対策を含む避難所等の公衆衛生対策 も含まれている ${ }^{9}$. 今回の感染対策 JMATはJMATと して避難所の感染対策支援を行った初めてのケースであ るが, 当初, 感染対策 JMAT の活動と保健師の避難所 支援活動が重複していた。鹿児島県医師会のロジスティ クス担当と地元医師会・行政とが密接に連携し，また JMAT と保健師チームなどさまざまな団体が，それぞ れの専門性を生かし各チームが自律しつつ, かつ目的を 共有し全体では一体となった活動を展開することが可能 となり，また慢性期の避難所感染対策支援への円滑な引 継ぎにつながった. 今後避難所の感染対策を含む保健活 動は保健所や災害時健康危機管理支援チーム（DHEAT） が中心になってくることと思われる，一方，医療機関に は感染対策の専門家が多数おり，医療支援における避難 


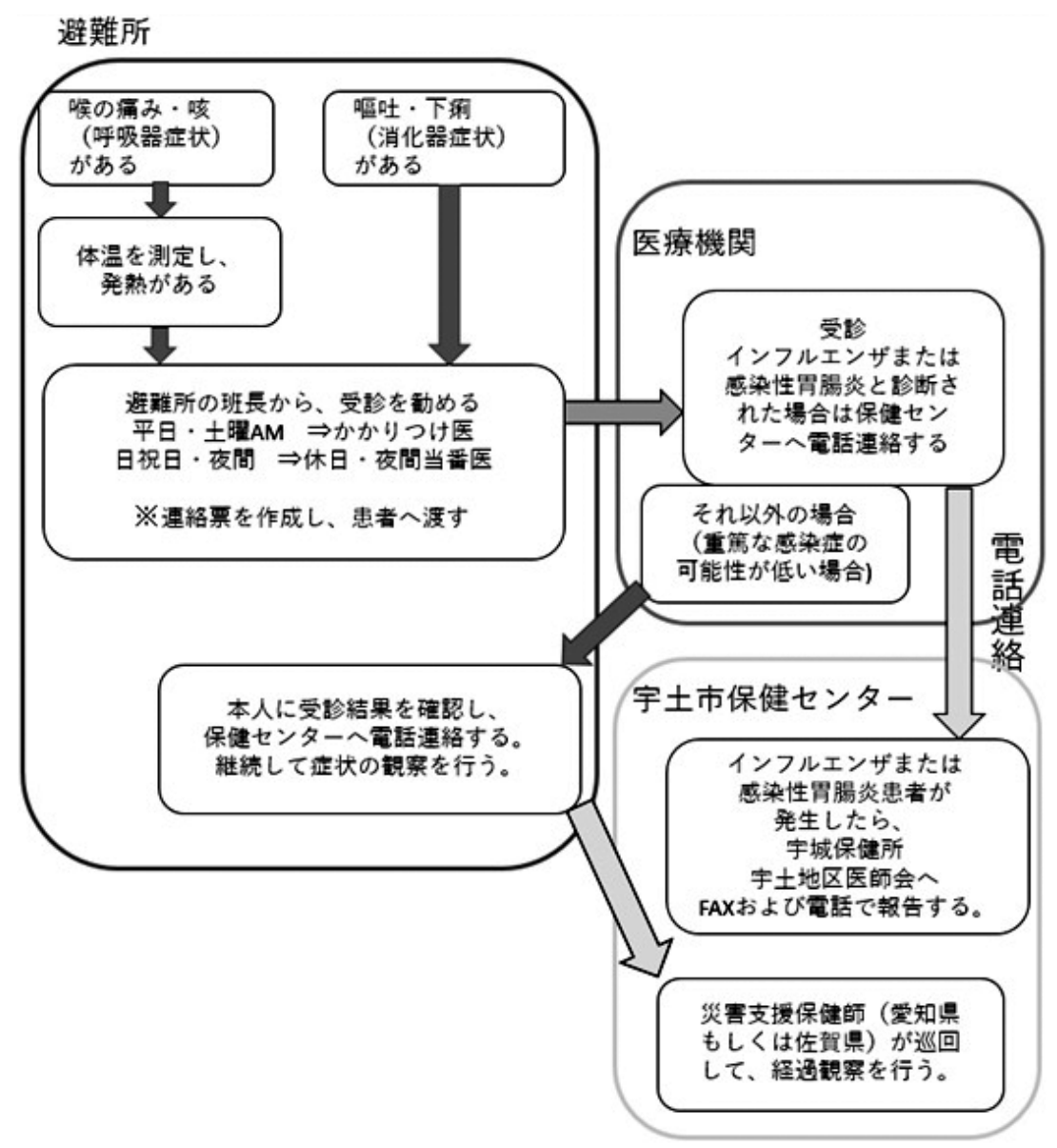

図 4 感染対策 JMAT 終了後の活動フロー

所の感染対策活動にも重要な役割をもつ.このことから 平時の感染対策やサーベイランスをDHEAT が中心と なって行い, 感染症が発生した場合は感染対策活動を専 門とする医療支援班がサポートするなどの役割分担が考 えられる. 避難所の感染対策は発災直後のライフライン が寸断された急性期から医療支援が少なくなる慢性期ま で求められる.今回避難所の感染対策支援活動は JMAT の引き上げに伴い, 我々は医療支援班と保健活動・行政 の役割分担を行い，また少なくなる医療支援を地元医療 団体に担ってもらえるようなスキームを作り，宇土地区 医師会 - 宇土市 - 愛知県 - 佐賀県からの応援自治体保健 師活動チームに引き継いた（図 4). 感染症発症例が探 知された場合, 感染管理専門家が行政を補佐し, 避難所 の疫学的評価, 発症者の重症度などの臨床的評価, 避難 所内感受性者の評価, 市中での流行状況の評価, ワクチ ン・抗ウイルス薬などの特異的介入策の必要性などをあ わせてリスク評価し, 感染対策を行っていくことが重要 である．今回の活動やインフルエンザ発生事例への対応 をうけ, 熊本感染管理ネットワークと国立感染症研究所 感染症疫学センター, 支援を行った医療機関や保健所関 係者が参加し「避難所で探知された感染症事例のリスク
評価の手法について〜熊本地震の経験から」のワーク ショップが開催され, 避難者が感染症を発症した場合の 感染管理専門家によるリスク評価法も作成された（表 $3)^{10)}$. 感染対策に関するリスクアセスメントや患者発生 時の対応について，保健福祉や災害医療や感染制御の医 療関係者間で共有化し支援体制を整備しておくことも必 要である。

発生時期がインフルエンザ流行期と重なる場合，避難 所ではインフルエンザの多発事例が発生するリスクがあ り，東日本大震災の際には避難所でのアウトブレイクが 発生したとの報告がある ${ }^{11}$. 2016 年熊本地震の発災時期 はインフルエンザの流行が終息に向かう状況で, 発症者 の多くは B 型であった ${ }^{12}$. 今回の活動中避難所で 3 事例 のインフルエンザ発生があったが，感染対策の実施，発 症者がみられた場合の隔離といった対策を迅速に実施し， 感染拡大は起こらなかった。抗インフルエンザ薬の予防 投与は，投与が長期にわたり，治療薬が枯渴するリスク があることから，原則的には推奨しない ${ }^{13)}$, 集団感染と して発生した場合には濃厚接触者のうち, 八イリスク者 に予防投与を考慮する，避難所内の伝播拡大を抑えるこ とができない場合は健常者を含めて予防投薬を考慮す 
表 3 避難所において「インフルエンザ」と診断された事例が発生した場合の感染管理専門家によるリスク評価

\begin{tabular}{|c|c|c|c|}
\hline キーワード & カテゴリー & 評価のポイント & 対応 (行政とともに行う) \\
\hline 変か? & $\begin{array}{l}\text { 疫学的 } \\
\text { 評価 }\end{array}$ & $\begin{array}{l}\text { クラスタリング(接 } \\
\text { 点の多いものの化 } \\
\text { における複数症 } \\
\text { 例の発生) }\end{array}$ & $\begin{array}{l}\text { 症例の年齢・性別・発症日・ワクチン歴・入院の要の有無等についてとりまとめ, 行政に伝 } \\
\text { え, 必要な介入に討する. } \\
\text { 感染者を適切に隔離する方法を考える. } \\
\text { 避難所内で, 手洗い, うがい指導を行う. } \\
\text { 状況に応じて, 予防的なマスク着用について検討する. } \\
\text { 他に感染者がいないかを調査する (避難所管理者への報告のお願いについての掲示も活用) } \\
\text { 症例の接触者の健康観察を十分に行う. }\end{array}$ \\
\hline \multirow{2}{*}{ ひどいか? } & \multirow{2}{*}{$\begin{array}{l}\text { 臨床的 } \\
\text { 評価 }\end{array}$} & 死亡 & 診察した医療機関に対し行政への連絡を勧める. \\
\hline & & 入院要 & 重症例については, 行政に一報するとともに適切な医療機関に搬送する. \\
\hline \multirow{5}{*}{ 拡がるか? } & \multirow{2}{*}{$\begin{array}{l}\text { 避難所内 } \\
\text { の評価 }\end{array}$} & 概数 & すべて感受性ありと考える. \\
\hline & & $\begin{array}{l}\text { 重症化リスクの } \\
\text { 高い人数 }\end{array}$ & $\begin{array}{l}\text { 乳幼児, 高齢者, 妊婦, 基礎疾患を持っている人など, インフルエンザの重症化リスクが高 } \\
\text { い人を感防謢する方法についても討する. }\end{array}$ \\
\hline & \multirow[t]{2}{*}{$\begin{array}{l}\text { 市中での } \\
\text { 流行状況 }\end{array}$} & 高いレベルの流行 & $\begin{array}{l}\text { 避難所全体において, 手洗い等, 必要な感染対策を強化する. } \\
\text { 持ち込まれやすい, 流行しやすい季節であることから, 避難所内のサーベイランスを強化する. } \\
\text { 感染者を適切に隔離する. 感染者がいたずらに不当な扱いを受けなよう配慮をする. 隔離除の条件を明記する. } \\
\text { 避難所の過密度. 咳嗽者の数も合わせて評価し適切な対応を検討する. }\end{array}$ \\
\hline & & $\begin{array}{l}\text { 流行は低調で, 散 } \\
\text { 発例と判断 }\end{array}$ & $\begin{array}{l}\text { 感染者の隔離が有効であると考えられる. } \\
\text { サーベイランス強化. 避難所の過密度. 咳嗽者の数も合わせて評価する. } \\
\text { 感染者がいたずらに不当な扱いを受けないよう配慮をする. }\end{array}$ \\
\hline & 特異的 & $\begin{array}{l}\text { ワクチン・抗ウイル } \\
\text { ス薬など特異的な } \\
\text { 染予防策がある }\end{array}$ & $\begin{array}{l}\text { 定期の接種時期であれば, 定期接種を勧奨する. } \\
\text { 重症化リスクの高い人については症例の発生の有無に関わらず推奨する. } \\
\text { 抗インフルエンザ薬の予防投薬は状況に応じて考慮する. }\end{array}$ \\
\hline
\end{tabular}

文献 12 より一部改変

る14) ことが推奨されている. 今回インフルエンザ発生の 1 事例で避難所の過密状況と接触度を考慮し予防投与を 行ったが, 対応後にインフルエンザ発生を認めず, 予防 投与がアウトブレイクの回避につながった可能性がある. 予防投与の必要性に関しては, 発生数 - 避難所の過密度 といった状況や発症者のインフルエンザの亜型によって 薬剤投与の必要性や薬剤選択をどのように行うか, さら なる検討が必要と思われる。

医師会・自治体と協働した早期からの JMAT 感染対 策活動は, 避難所の感染症多発事例回避につながったと 考えられる。

謝 辞 : 本活動に参加いただいた, 鹿児島感染制御ネットワー ク 宮原宏典先生, 松尾敏明先生, 小川信先生, 鳥越玉美氏, 吉 満桂子氏, 吉森みゆき氏, 立和名聖子氏, 土屋香代子氏, 中野智 子氏, 活動に協力いただいた, 鹿児島県医師会 池田玩哉医師会 長, 坂上弘憲氏, 宇土地区医師会 尾崎建前医師会長, 本多靖洋 先生, 上田保範氏, 宇土市健康福祉部 伊藤順子氏, 渋谷区保健 所 小林一司先生, 愛知県 白崎節子氏, 木村朋子氏, 佐賀県川原 照美氏に深謝申し上げます。

利益相反自己申告 : 申告すべきものなし.

\section{文献}

1）国立感染症研究所感染症疫学センター：避難所におけるリ スクアセスメントの方法・考え方について : http://www.ni id.go.jp/niid/images/idsc/disasters/RAguidance20160419.p df

2）片山貴文, 神崎初美, 東ます久, 野澤美江子, 白川 功, 山 本あい子：被災者の殺到時や停電，通信途絶時の使用を想 定した避難所の看護記録シートの開発．兵庫県立大学看護 学部・地域ケア開発研究所紀要 2009; 16: 51-67.

3）東北感染症危機管理ネットワーク：避難所生活における感 染管理上のリスクアセスメント：http://www.tohoku-icnet. ac/shinsai/images/pdf/hotline01.pdf

4）遠藤幸男：福島県県南地域における避難所サーベイランス. Infectious Agents Surveillance Report 2011; 32: S7.

5）加來浩器, 松舘宏樹, 工藤啓一郎, 野原 勝, 小石明子, 外 舘善裕, 他：岩手県における避難所サーベイランスと感染 対策. Infectious Agents Surveillance Report 2011; 32: S13.

6）田中 圭：災害対応のキーワード “CSCATTT”：有嶋拓郎, 東岡宏明監修, Disaster ABC コースガイドブック一地域密 着型の病院災害訓練, 荘道社, 東京, 2011. p. 10-20.

7）増田克善：電子災害診療記録システム, 災害現場で使って みた. 日経デジタルヘルス：http://techon.nikkeibp.co.jp/a tcl/feature/15/327441/012600167/?ST =health\&P=1

8）東北感染症危機管理ネットワーク：避難所におけるトイレ 清掃のポイント : http://www.tohoku-icnet.ac/shinsai/ima ges/pdf/hotline07.pdf

9）日本医師会：東日本大震災における JMAT 活動について： http://dl.med.or.jp/dl-med/eq201103/jmat/jmatandjmat22 0160321.pdf

10）熊本感染管理ネットワーク・厚生労働行政推進調査事業費 補助金「新興・再興感染症の発生に備えた感染症サーベイ 
ランスの強化とリスクアセスメント」.

11) Hatta M, Endo S, Tokuda K, Kunishima H, Arai K, Yano $\mathrm{H}$, et al: Post-tsunami outbreaks of influenza in evacuation centers in Miyagi Prefecture, Japan. Clin Infect Dis 2012; 54: e5-7.

12）熊本県：感染症発生情報週報（第 17 週報）：http://www.p ref.kumamoto.jp/kiji_2629.html : 平成 29 年 3 月 11 日現在.

13）国立感染症研究所感染症情報センター：被災地におけるイ ンフルエンザの予防対策について : http://idsc.nih.go.jp/ea
rthquake2011/IDSC/20110322infle.html.

14）東北感染症危機管理ネットワーク：避難場所における抗イ ンフルエンザ薬の予防投与について vol.3.0 : http://www.to hoku-icnet.ac/shinsai/images/pdf/hotline05.pdf

〔連絡先：干890-8520 鹿児島市桜ケ丘 8 丁目 35-1 鹿児島大学病院医療環境安全部感染制御部門 川村英樹 E-mail: hidekik@m2.kufm.kagoshima-u.ac.jp]

\title{
Support for Infection Control in Evacuation Centers Following 2016
} Kumamoto Earthquakes by Kagoshima Prefecture Medical Association Team

\author{
Hideki KAWAMURA ${ }^{1,2)}$, Koichi ToKUdA ${ }^{1,2)}$, Masayuki KAWAKAMI'), Toshiaki ArImurA ${ }^{2)}$, \\ Tatsuya KAWAGUCHI ${ }^{3)}$, Tamano MATSUI ${ }^{4)}$ and Junichiro Nishi ${ }^{1,2)}$ \\ ${ }^{1)}$ Department of Infection Control and Prevention, Division of Medical and Environmental Safety, Kagoshima University Hospital, \\ ${ }^{2)}$ Kagoshima Infection Control Team Network, \\ 3) Department of Hematology and Infectious Diseases, Kumamoto University Graduate School of Medical Sciences, \\ ${ }^{4)}$ Infectious Disease Surveillance Center, National Institute of Infectious Diseases
}

\section{Abstract}

Doctors and nurses certified in infection control joined the Japan Medical Association Team (JMAT) of Kagoshima Prefecture to support the local medical association and administrative healthcare teams with respect to infection prevention activities at evacuation centers from April 21, 2016 (5 days after the main event) to May 1, 2016 (15 days after the main event) in Uto-city after the 2016 Kumamoto earthquakes. The activities comprised risk assessment pertaining to the outbreaks of infections at the evacuation centers, establishment of symptomatic surveillance, and distribution of antiseptics and equipment for infection prevention. There were no outbreaks of infectious diseases such as those of influenza and infectious gastroenteritis at the evacuation centers in Uto-city. Our activities were effective in the prevention of outbreaks at these centers. It is important to prepare a structure to support infection prevention including medical support team and disaster health emergency assistance team at the time of disasters at evacuation centers.

Key words: 2016 Kumamoto earthquakes, disaster support, influenza, infectious gastroenteritis 